\title{
A FRAMEWORK FOR MEASURING AND IMPROVING EFFICIENCY IN DISTRIBUTION CHANNELS
}

\author{
Milan Andrejić ${ }^{1}$, Milorad Kilibarda ${ }^{2}$ \\ ${ }^{1,2}$ University of Belgrade, Faculty of Transport and Traffic Engineering, Vojvode Stepe 305, 11000 \\ Belgrade, Serbia
}

Received 10 May 2016; accepted 5 Jun 2016

\begin{abstract}
Distribution of products is largely conditioned by the efficiency of logistics processes. The efficient logistics processes provide loyal and satisfied customers, dominant position on the market and revenue. In this paper new approach for measuring and improving efficiency of logistics processes in distribution channel is proposed. Model based on the Principal Component Analysis - Data Envelopment Analysis approach evaluates efficiency of ordering, warehousing, packaging, inventory management and transport processes as well as distribution channel efficiency. Proposed approach also gives information about corrective actions for efficiency improvement. According results efficiency should be improved in several ways: information system improvement, failures decreasing, utilization increasing and output increasing. The results of proposed approach testing show great applicability of developed approach.
\end{abstract}

Keywords: logistics processes, efficiency, measuring, improving.

\section{Introduction}

Numerous logistics processes are realized in distribution channels. The realization of mentioned processes largely affects product distribution and customer satisfaction. The importance of logistics in the distribution channels has been widely discussed in the literature. Product availability depends directly on the realization of logistics processes and activities (Kotzab and Bjerre, 2005). Distribution channels can be divided in different ways. One of the most important is distribution channels of 3PL provider (Rushton et al., 2006). The introduction of outsourcing in distribution channels leads to the expansion of companies specialized in the realization of logistics activities and processes in the distribution channels (Higginson and Bookbinder, 2005). For logistics process monitoring different indicators are used (Neely et al., 1995; Fawcett and Cooper, 1998; Frazelle, 2002). One of the most relevant is efficiency. The problem of measuring and improving efficiency of logistics processes is recognized in literature (Ross and Droge, 2002; Chakraborty et al., 2011). According Andrejić (2015) there are different problems in the process of measuring and improving efficiency: indicator selection, efficiency measurement levels, efficiency decomposition, conflicting goals, shared resources, measuring efficiency of supply chains, etc. There is a lack of papers in the literature that analyze efficiency of logistics processes in distribution channels. The most of the papers in the literature are focused

${ }^{1}$ Corresponding author: m.andrejic@sf.bg.ac.rs 
on the measuring efficiency of independent logistics systems (Hackman et al., 2001; Hamdan and Rogers, 2009) or supply chains (Hervani et al., 2005; Kalenoja et al., 2011; Sarkis and Talluri, 2004). Mentioned papers did not take into account the place and role of logistics systems in distribution channel. In this paper the fundamental logistics processes in distribution channel are identified. The special emphasize is given to measuring efficiency and definition of corrective actions for improving efficiency. Models proposed in paper provide accurate information about necessary improvement for all logistics processes. The paper is organized as follows. The next section gives the detailed description of observed processes. Proposed approach for measuring efficiency of logistics processes in distribution channel is described in third section. In fourth section possibilities for improving efficiency of logistics processes in distribution channel are described. At the end of the paper concluding remarks and directions of future research are given.

\section{Logistics Processes in Distribution Channel}

The first process is product ordering with two basic aspects (Andrejić, 2015). The first aspect of product ordering is ordering from suppliers, while the second is customer ordering (Fig. 1). The customer demands can be made in several ways: e-mail, show room, telephone, etc. All activities in this process relate to information flow. The next process is warehousing. Activities in this process may be divided in two segments. In the first segment are activities of goods receiving, putting away and storage while in the second are activities of order processing and preparing for delivery. Warehousing largely depends on speed of information exchange. Order picking process is the crucial process in warehouses. The following is the process of packaging. This process is realized through merging goods from different segments, forming transport units, goods inspection, as well as the loading goods in vehicles. Packaging is in direct relation with the order processing and distribution (transport).

The transport is key processes in the product distribution (Rushton et al., 2006). The selection of distribution strategy is very important. Generally there are two situations. The first is strategy of fast delivery, where the demands are realized immediately with very low possibilities of merging two or more demands. The second is strategy with a longer lead time, where different demands are aggregated in time and then realized and delivered. This process largely affects customer satisfaction. The process that is related to all mentioned processes is inventory management. The last process is unloading in the retail stores. 


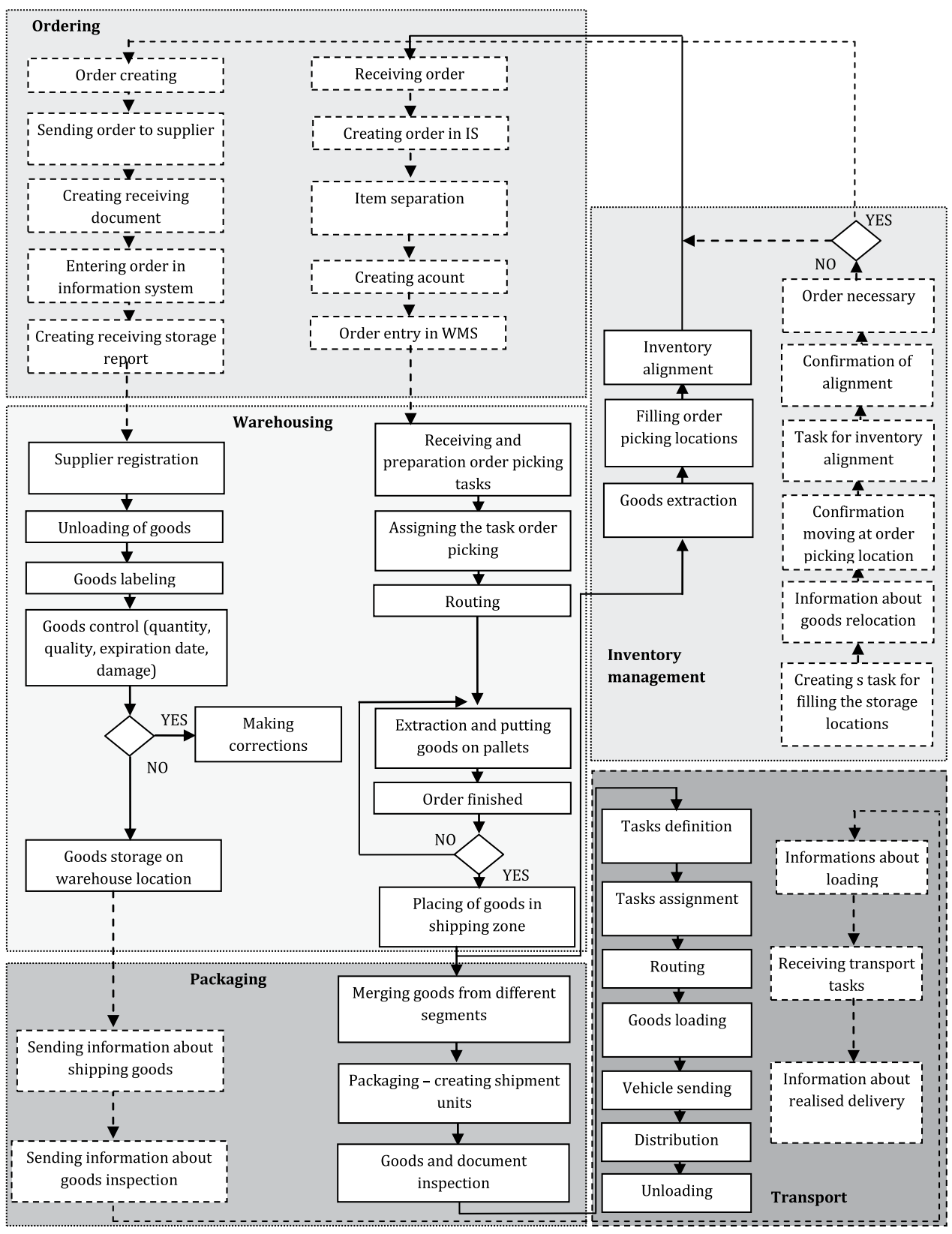

Fig. 1.

Logistics Processes in Distribution Channel

Source: Andrejić et al. (2015) 


\section{Efficiency Measuring}

In order to evaluate efficiency of certain logistics processes in different situations several scenarios are generated. Three critical decisions are identified. In that manner ordering (show room or internet), order picking (paper or advanced) and distribution strategy (fast or aggregation) generated eight different scenarios (eight DMUs - Decision Making Units). The small number of DMUs and large number of indicators directly affects the problem of applications of standard model for efficiency measuring in literature. Andrejić (2015) proposed new model for measuring efficiency of distribution channel:

$$
E_{d c}=E_{o}+E_{w}+E_{p}+E_{t}+E_{i m}+E_{u}
$$

The efficiency of distribution channel $\left(E_{d c}\right)$ is the sum of efficiencies of all logistics processes: ordering process $\left(E_{0}\right)$, efficiency of warehousing process $\left(E_{w}\right)$, efficiency of packaging $\left(E_{p}\right)$, efficiency of transport
$\left(E_{t}\right)$, efficiency of inventory management $\left(E_{i m}\right)$ and the efficiency of unloading $\left(E_{u}\right)$. For the process of measuring efficiency in distribution channels, different models are used. A large number of different indicators describe mentioned processes. As input indicators in this paper are used: employees, time of activities realization, equipment, order picking transactions, warehouse overtime, electricity costs, other energy costs, costs of packaging materials, inventories, number of pallet places, vehicles, fuel consumption, driver overtime, maintenance costs, ordering costs and unloading costs (Table 1). On the other side seventeen output indicators are used: number of deliveries, realized demands, inventory turnover, warehouse space utilization, failures in different sectors, distance driven, vehicle space utilization, vehicle, time utilization, turnover, packaged units, transported pallets, ordering speed, unloading speed (Table 2). The values are normalized values proposed in Andrejić (2015).

\section{Table 1}

\section{Input Indicators of Logistics Processes in Distribution Channels}

\begin{tabular}{|lccccccccc|}
\hline $\begin{array}{l}\text { DMU/ } \\
\text { Scenario }\end{array}$ & $\begin{array}{c}\text { Employees - } \\
\text { warehouse }\end{array}$ & $\begin{array}{c}\text { Time - } \\
\text { activities }\end{array}$ & Equipment & $\begin{array}{c}\text { Order picking } \\
\text { transaction }\end{array}$ & $\begin{array}{c}\text { Warehouse } \\
\text { overtime }\end{array}$ & $\begin{array}{c}\text { Electricity } \\
\text { Other energy Employees- } \\
\text { costs }\end{array}$ & $\begin{array}{c}\text { Packaging } \\
\text { packaging } \\
\text { material costs }\end{array}$ \\
\hline DMU 1 & 1.05 & 1.30 & 1.05 & 1.05 & 1.30 & 0.77 & 0.77 & 1.05 & 0.99 \\
DMU 2 & 0.97 & 1.30 & 0.97 & 0.97 & 1.30 & 0.85 & 0.85 & 0.97 & 1.19 \\
DMU 3 & 0.89 & 0.70 & 0.89 & 0.89 & 0.70 & 0.94 & 0.94 & 0.89 & 0.99 \\
DMU 4 & 0.85 & 0.70 & 0.85 & 0.85 & 0.70 & 1.07 & 1.07 & 0.85 & 1.19 \\
DMU 5 & 1.21 & 1.30 & 1.20 & 1.21 & 1.30 & 0.94 & 0.94 & 1.21 & 0.99 \\
DMU 6 & 1.09 & 1.30 & 1.09 & 1.09 & 1.30 & 1.07 & 1.07 & 1.09 & 0.99 \\
DMU 7 & 1.01 & 0.70 & 1.01 & 1.01 & 0.70 & 1.07 & 1.07 & 1.01 & 0.83 \\
DMU 8 & 0.93 & 0.70 & 0.93 & 0.93 & 0.70 & 1.28 & 1.28 & 0.93 & 0.83 \\
\hline & Inventory & Pallet & Employees- & Vehicles & Fuel & Driver & Maintenance & Ordering & Unloading \\
& value & places & transport & & consumption & overtime & costs & costs & costs \\
\hline DMU 1 & 1.17 & 1.05 & 1.05 & 1.05 & 1.35 & 1.35 & 1.15 & 0.95 & 1.10 \\
DMU 2 & 1.00 & 0.97 & 0.97 & 0.97 & 0.65 & 0.65 & 0.85 & 1.00 & 0.90 \\
DMU 3 & 1.17 & 0.89 & 0.89 & 0.89 & 1.35 & 1.35 & 1.15 & 1.20 & 1.20 \\
DMU 4 & 1.00 & 0.85 & 0.85 & 0.85 & 0.65 & 0.65 & 0.85 & 1.05 & 0.95 \\
DMU 5 & 1.00 & 1.21 & 1.21 & 1.20 & 1.35 & 1.35 & 1.15 & 0.80 & 1.05 \\
DMU 6 & 0.83 & 1.09 & 1.09 & 1.09 & 0.65 & 0.65 & 0.85 & 0.85 & 0.85 \\
DMU 7 & 1.00 & 1.01 & 1.01 & 1.01 & 1.35 & 1.35 & 1.15 & 0.90 & 1.00 \\
DMU 8 & 0.83 & 0.93 & 0.93 & 0.93 & 0.65 & 0.65 & 0.85 & 0.75 & 0.70 \\
\hline
\end{tabular}


Table 2

Output Indicators of Logistics Processes in Distribution Channels

\begin{tabular}{|c|c|c|c|c|c|c|c|c|c|}
\hline DMU/Scenario & $\begin{array}{l}\text { Number of } \\
\text { deliveries }\end{array}$ & $\begin{array}{l}\text { Realized } \\
\text { demands }\end{array}$ & $\begin{array}{l}\text { Inventory } \\
\text { turnover }\end{array}$ & $\begin{array}{c}\text { Warehouse space } \\
\text { utilization }\end{array}$ & $\begin{array}{l}\text { Failure - short } \\
\text { expired time }\end{array}$ & $\begin{array}{l}\text { Distance } \\
\text { driven }\end{array}$ & $\begin{array}{c}\text { Vehicle space } \\
\text { utilization }\end{array}$ & \multicolumn{2}{|c|}{$\begin{array}{l}\text { Vehicle time } \\
\text { utilization }\end{array}$} \\
\hline DMU 1 & 1.35 & 0.99 & 0.80 & 0.85 & 0.76 & 1.35 & 0.65 & \multicolumn{2}{|c|}{0.65} \\
\hline DMU 2 & 0.65 & 1.19 & 0.80 & 1.15 & 0.64 & 0.65 & 1.35 & \multicolumn{2}{|c|}{1.35} \\
\hline DMU 3 & 1.35 & 0.99 & 0.80 & 0.85 & 0.92 & 1.35 & 0.65 & \multicolumn{2}{|c|}{0.65} \\
\hline DMU 4 & 0.65 & 1.19 & 0.80 & 1.15 & 1.09 & 0.65 & 1.35 & \multicolumn{2}{|c|}{1.35} \\
\hline DMU 5 & 1.35 & 0.99 & 1.20 & 0.85 & 1.00 & 1.35 & 0.65 & \multicolumn{2}{|c|}{0.65} \\
\hline DMU 6 & 0.65 & 0.99 & 1.20 & 1.16 & 0.78 & 0.65 & 1.35 & \multicolumn{2}{|c|}{1.35} \\
\hline DMU 7 & 1.35 & 0.83 & 1.20 & 0.85 & 2.55 & 1.35 & 0.65 & \multicolumn{2}{|c|}{0.65} \\
\hline DMU 8 & 0.65 & 0.83 & 1.20 & 1.16 & 2.34 & 0.65 & 1.35 & \multicolumn{2}{|c|}{1.35} \\
\hline & $\begin{array}{l}\text { Failure } \\
\text { (quantity) }\end{array}$ & Turnover & $\begin{array}{l}\text { Packaged } \\
\text { units }\end{array}$ & $\begin{array}{l}\text { Transported } \\
\text { pallets }\end{array}$ & $\begin{array}{l}\text { Failure } \\
\text { (delays and } \\
\text { damage) }\end{array}$ & $\begin{array}{c}\text { Ordering } \\
\text { speed }\end{array}$ & $\begin{array}{l}\text { Ordering } \\
\text { failure }\end{array}$ & $\begin{array}{c}\text { Unloading } \\
\text { speed }\end{array}$ & $\begin{array}{l}\text { Unloading } \\
\text { failures }\end{array}$ \\
\hline DMU 1 & 0.74 & 0.91 & 0.73 & 0.91 & 0.91 & 0.70 & 1.10 & 0.70 & 1.05 \\
\hline DMU 2 & 1.54 & 0.74 & 0.95 & 0.74 & 0.91 & 0.80 & 1.15 & 0.80 & 1.10 \\
\hline DMU 3 & 0.74 & 0.95 & 0.77 & 0.95 & 2.00 & 0.85 & 1.00 & 0.90 & 1.00 \\
\hline DMU 4 & 1.54 & 0.77 & 0.99 & 0.77 & 2.00 & 0.90 & 0.95 & 0.95 & 0.70 \\
\hline DMU 5 & 0.74 & 1.23 & 0.80 & 1.23 & 0.67 & 0.95 & 0.90 & 1.00 & 0.90 \\
\hline DMU 6 & 1.54 & 0.98 & 1.28 & 0.98 & 0.67 & 1.00 & 0.85 & 1.15 & 0.60 \\
\hline DMU 7 & 0.74 & 1.40 & 1.02 & 1.40 & 1.11 & 1.10 & 0.80 & 1.20 & 0.55 \\
\hline DMU 8 & 1.54 & 1.02 & 1.46 & 1.02 & 1.11 & 1.00 & 0.70 & 1.10 & 0.4 \\
\hline
\end{tabular}

The ordering process, packaging and unloading are evaluated using the CCR DEA model because small number of indicators (Charnes et al., 1978; Zhu, 2008). In order to estimate DMU efficiency it is necessary to have data for consumed input and realized output variables. The following notation is introduced in DEA terminology. A set of DMUs makes $n$ DMU $(j=1,2, \ldots, n)$, where each input is characterized by $m$ input ( $i=$ $1,2, \ldots, m)$ and $s$ output values $(r=1,2, \ldots$, s). The value of $i$ input variable is denoted as $x_{i j}$, while $y_{r i}$ denotes the value of $r$ output variables of $\mathrm{DMU}$. Weighting coefficients are connected to all inputs and outputs and are marked with $v_{i}$ and $u_{r}$ respectively and they present decision variables. In order to estimate DMU efficiency of observed set it is necessary to perform $n$ independent estimations where $\mathrm{DMU}_{k}(k=1, \ldots, n)$ presents the process whose efficiency is estimated. In that case, the primal CCR (multiplier form) model is as follows:

$\operatorname{Max} \sum_{r=1}^{s} u_{r} y_{r k}$ $\sum_{i=1}^{m} v_{i} x_{i k}=1$

$\sum_{r=1}^{s} u_{r} y_{r k}-\sum_{i=1}^{m} v_{i} x_{i k} \leq 0, j=1,2, \ldots, n$

$v_{i} \geq 0, i=1, . ., m$

$u_{r} \geq 0, r=1, . ., s$

A large number of indicators that describe warehousing process, inventory management and transport is realized with model based on the Principal Component Analysis - Data Envelopment Analysis (Adler and Golany, 2001; Adler and Golany, 2002; Andrejić and Kilibarda, 2015):

$\max _{U_{P C}, V_{P C}} U_{P C} Y_{P C}^{a}$

Subject to:

$V_{P C} X_{P C}^{a}=1$

$V_{P C} X_{P C}-U_{P C} Y_{P C} \geq 0$

$V_{P C_{i}}-V_{P C_{i+1}} \geq 0$, for $i=1, \ldots m-1$, where $m P C s$ are analyzed 
$U_{P C_{i}}-U_{P C_{i+1}} \geq 0$, for $i=1, \ldots m-1$, where $m P C s$ are analyzed

$V_{P C}^{t} L_{x} \geq 0$

$U_{P C}^{t} L_{y} \geq 0$

$V_{P C}, U_{P C}$, free

$V_{P C}$ and $U_{P C}$ represents vector of weights assigned to inputs and outputs PCs, $X_{P C}$ and $Y_{P C}$ represent the input and output matrix, while $L_{x}$ and $L_{y}$ relate to the matrix of the PCA linear coefficients of input and output data. Applying previous models efficiency scores for logistics processes in different scenarios are made. The results are shown in Table 3. The first process in distribution channel and the process where customer has important role is ordering process. Using identified parameters efficiency of ordering process is evaluated. The most efficient is the eight scenario (DMU 8), while the less efficient is the first scenario (DMU 1). The ordering process is more efficient in the internet ordering, advanced order-picking systems and distribution strategy with aggregation.

\section{Table 3}

Efficiency of Logistics Processes in Distribution Channel

\begin{tabular}{|c|c|c|c|c|c|c|c|c|c|}
\hline DMU & Scenario* & Ordering & Warehousing & Packaging & $\begin{array}{l}\text { Inventory } \\
\text { management }\end{array}$ & Transport & Unloading & Sum & Rank \\
\hline DMU 1 & A0 B0 C0 & 0.36 & 0.82 & 0.44 & 0.62 & 0.64 & 0.31 & 3,20 & 8 \\
\hline DMU 2 & $\mathrm{~A} 0 \mathrm{~B} 0 \mathrm{C} 1$ & 0.41 & 1.00 & 0.62 & 0.90 & 0.72 & 0.48 & 4,13 & 5 \\
\hline DMU 3 & $\mathrm{~A} 0 \mathrm{~B} 1 \mathrm{C} 0$ & 0.37 & 1.00 & 0.55 & 0.74 & 0.77 & 0.39 & 3,80 & 7 \\
\hline DMU 4 & $\mathrm{~A} 0 \mathrm{~B} 1 \mathrm{C} 1$ & 0.45 & 1.00 & 0.74 & 1.00 & 0.79 & 0.56 & 4,54 & 4 \\
\hline DMU 5 & A1 B0 C0 & 0.69 & 0.69 & 0.46 & 0.66 & 0.81 & 0.52 & 3,84 & 6 \\
\hline DMU 6 & A1 B0 C1 & 0.68 & 0.71 & 0.75 & 1.00 & 0.97 & 0.73 & 4,83 & 2 \\
\hline DMU 7 & A1 B1 C0 & 0.71 & 0.63 & 0.70 & 0.95 & 0.99 & 0.69 & 4,68 & 3 \\
\hline \multirow[t]{4}{*}{ DMU 8} & A1 B1 C1 & 1.00 & 0.65 & 1.00 & 1.00 & 1.00 & 1.00 & 5,65 & 1 \\
\hline & Average & 0.58 & 0.81 & 0.66 & 0.86 & 0.84 & 0.58 & & \\
\hline & \multicolumn{3}{|c|}{${ }^{*} A O-$ show room ordering } & \multicolumn{2}{|c|}{ B0-paper order picking } & \multicolumn{4}{|c|}{ CO-fast delivery } \\
\hline & \multicolumn{3}{|c|}{ A1-internet ordering } & \multicolumn{2}{|c|}{ B1-advanced order picking } & & \multicolumn{3}{|c|}{ C1-delivery with aggregation } \\
\hline
\end{tabular}

With the average efficiency score of 0.81 is relatively efficient process. In the scenario of internet ordering, advanced order picking system and fast distribution. This can be explained with intensive ordering of small demands with fast delivery. The show room is the efficient solution for warehousing process. It is the consequence of direct contact of products and customers, and the better exchange of information about inventories. The principal component analysis results are shown in Table 4 . The nine indicators constitute three artificial components (two inputs and one output).

The special importance in the first component have time indicators of activity realization, equipment indicators, indicators of employees. This component includes more than $70 \%$ of total variance. Energy indicators are the most influential in the second component. In the output indicators the realized deliveries and total failures are the most important. 


\section{Table 4}

Principal Components for Warehousing Process

\begin{tabular}{|c|c|c|c|c|c|}
\hline Input & & PC1 & & $\mathrm{PC} 2$ & \\
\hline Employees - warehouse & & 0.889 & & 0.432 & \\
\hline Time - activities (h) & & 0.934 & & -0.104 & \\
\hline Equipment & & 0.889 & & 0.432 & \\
\hline Order picking transactions & & 0.889 & & 0.432 & \\
\hline Warehouse overtime & & 0.934 & & -0.104 & \\
\hline Electricity & & -0.643 & & 0.744 & \\
\hline \multirow[t]{2}{*}{ Other energy costs } & & -0.643 & & 0.744 & \\
\hline & Variance & & $70 \%$ & & $24 \%$ \\
\hline Output & & PC1 & & PC2 & \\
\hline Realized demands & & 0.793 & & & \\
\hline \multirow[t]{2}{*}{ Failures } & & 0.793 & & & \\
\hline & Variance & & $63 \%$ & & \\
\hline
\end{tabular}

The average efficiency of transport process is 0.84 . In the first scenario efficiency is the lowest. The efficiency of transport largely depends of aggregation strategy, advanced order picking system and internet ordering (Table 5). In that manner the largest efficiency score is in the eighth scenario. In the first component which explain $74 \%$ of total variance as the most influential indicators are energy consumption, maintenance costs, number of deliveries and driver overtime, while in the second are equipment and employees indicators. The output component consists of different indicators while the most influential are utilization factors, distance and failures.

\section{Table 5}

Principal Components for Transport Process

\begin{tabular}{lll}
\hline Input & PC1 & PC2 \\
\hline Employees- transport & 0.583 & 0.813 \\
Vehicles & 0.583 & 0.813 \\
Fuel consumption & 0.970 & -0.244 \\
Driver overtime & 0.970 & -0.244 \\
Maintenance costs & 0.970 & -0.244 \\
Deliveries & 0.970 & -0.244 \\
& Variance & \\
\hline Output & PC1 & \\
\hline Transported pallets & -0.686 & \\
Distance driven km & 0.992 & \\
Vehicle space utilization & 0.992 & \\
Vehicle time utilization & 0.992 & \\
Failures & 0.992 & \\
Turnover & -0.686 & \\
& Variance & \\
\hline
\end{tabular}


Inventory management as the process that bonding capital, largely depends of distribution system, way of ordering and order picking system. In the first scenario efficiency score is the lowest, while in fourth, sixth and eight scenarios is efficient. The results of principal component analyzes are shown in Table 6. Inventory level and warehouse size are the most important input components, while inventory turnover and failures are the most important in the first output component and warehouse space utilization in the second. Mentioned indicators largely affect efficiency of inventory management process and efficiency of distribution channel.

\section{Table 6}

Principal Components for Inventory Management Process

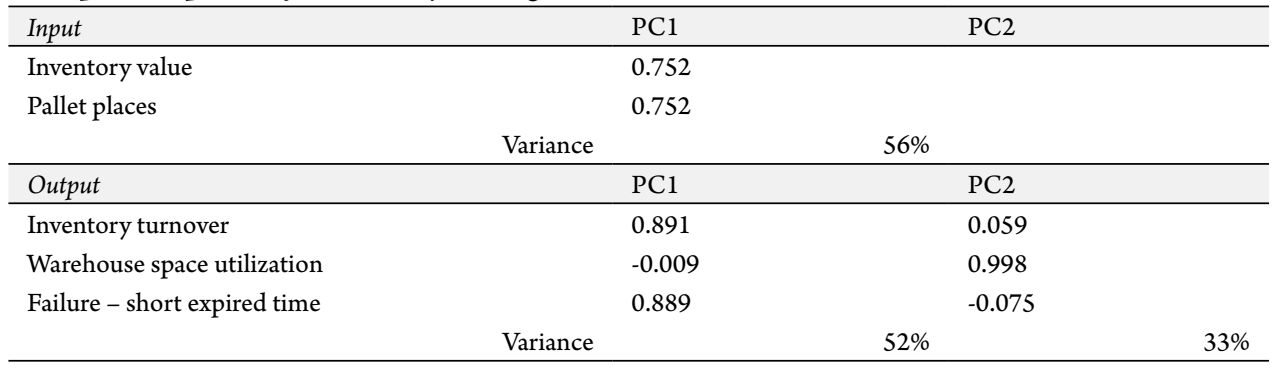

With the efficiency score 0.62 packaging process is the most problematic process. The first scenario is the worst combination for observed process. Distribution strategy is crucial for packaging process. Fast deliveries directly affect packaging material consumption and failure occurrence. Packaging efficiency directly affects the efficiency of distribution channel. Failures in the process of packaging may cause failures in transport process. The last in distribution processes is product unloading. Efficiency of unloading process is the result of speed of unloading and the level of failures. In the observed example the most efficient is the last scenario (internet ordering, advanced order picking and distribution (delivery) with aggregation). The results clearly indicate that the efficiency of individual processes depends on the strategy used. The last scenario is the most efficient. The best combination in the observed example is the internet ordering, advanced order picking and distribution (delivery) with aggregation. The scenario of show room ordering, paper order picking and fast delivery is the worst combination in the observed example. A common feature of the three least efficient scenarios is fast distribution strategy with a very short delivery time.

\section{Efficiency Improving}

The proposed models give important information about improving efficiency. The corrective actions relates to: improving information system, elimination of failures in transport process, warehouse process and inventory management, improving utilization and turnover (Table 7). 
Table 7

Potential Efficiency Improvement

\begin{tabular}{|c|c|c|c|c|}
\hline & $\begin{array}{c}\text { Information system } \\
\text { improvement }\end{array}$ & $\begin{array}{c}\text { Failures } \\
\text { decreasing }\end{array}$ & Utilization increasing & Output increasing \\
\hline Ordering process & $67 \%$ & $67 \%$ & / & / \\
\hline Warehousing & $19 \%$ & $19 \%$ & / & $19 \%$ number of deliveries \\
\hline Packaging & $34 \%$ & $34 \%$ & / & $34 \%$ increase of packaging units \\
\hline $\begin{array}{c}\text { Inventory } \\
\text { management }\end{array}$ & $14 \%$ & $14 \%$ & $14 \%$ space utilization & / \\
\hline Transport & $16 \%$ & $16 \%$ & $\begin{array}{l}16 \% \text { space and time vehicle } \\
\text { utilization }\end{array}$ & $\begin{array}{l}16 \% \text { increase of transported } \\
\text { pallets }\end{array}$ \\
\hline Unloading & $61 \%$ & $61 \%$ & / & / \\
\hline
\end{tabular}

\subsection{Information System Improvement}

The role of information in each system is to coordinate and support activities. In distribution systems it is necessary to integrated WMS (Warehouse Management System), TMS (Transport Management System) and other systems. It is also important to ensure easy exchange of information. As a result of rapid exchange of information and preparation of the necessary number of workers and other resources used in the packaging process it is possible to speed it up by $34 \%$. Efficiency of unloading process should be improved for $61 \%$ with information system improvement (Table 7).

\subsection{Failures Decreasing}

There are problems in the warehousing process when supplier supplies the goods of low quality and short expiration date. One of the basic steps is to define the level of quality and dimensions (specific check lists) of each unit of goods for each supplier. A relative small number of employers in this process limit the level of control. Putting away is very important activity in warehouse. A large number of mistakes are generated in this process. In real systems, order pickers realized this activity. Frequently relocation of order pickers from picking to putting away process greatly affects the occurrence of failures and reducing the level of customer service. They realize this process with insufficient attention. Assignment of smaller number of workers that will realize only putting away process should reduce failures to minimum. Inappropriate organization of space may affects failures. Managers in warehouse often have the goal of minimizing the space for order picking. One of the main aims is to reduce the effort in the order picking process. However, a large number of similar items at very short distances can cause failures. Order picking process is work and labor intensive process. The failures may be reduced if the order pickers strictly follow information system, and do not make decisions alone. Like in the process of order picking process the same situation is in the order processing, packaging and loading. It is very important to assign workers for particular processes. Reducing failures in transport refers to the reduction of losses in money, time, and users that are caused by theft, damage to goods, delays in delivery (Andrejić et al., 2015). According results in Table 7 warehousing process should improve efficiency reducing failures for $19 \%$. 
The warehouse failures often are transferred in transport process. The failures in transport can be decreased with good organization and process planning. Delivery delays can be overcome by better motivation of drivers and control of the movement of vehicles, as well as good planning routes and predictions of traffic congestion. Theft can be prevented with modern systems for protection of the cargo space. Systems of driver reward and punishment can additionally reduce the number of failures. In observed example failures in transport process should be decreased for $16 \%$.

The failures in inventory management directly affect the write-off of expired goods, which creates significant losses in the observed companies. A failure in the inventory is also the lack of goods required by the customer (Andrejić et al., 2015). The failures can be overcome on different ways: inventory monitoring with advances information systems, definition of delivery priority according expiration date, more precise estimation of the expected deliveries of suppliers and expected demands of customers. Video monitoring is one of the basic systems of protection against theft, etc. In order to improve efficiency failures in inventory management process should be decreased for $14 \%$.

\subsection{Utilization Increasing}

The resource utilization is very important for efficiency improvement. Warehouse space utilization increasing should lead to cost reduction and reduce the need for new facilities. There are numerous steps for mutilation increasing:

- review the layout of the facility;

- relocate battery chargers for forklifts from the facility;
- empty pallets stored outside the facility;

- relocate office space outside the warehouse, etc.

In the observed example warehouse space utilization should be increased for $14 \%$ applying mentioned corrective actions. The vehicle time and space utilization is very important for efficiency of transport process and distribution channel. For the better vehicle space utilization it is very important to merge demands and to use software for stacking of goods. On the other side vehicle time utilization can be improved with driver trainings, and advanced controlling systems. According results the vehicle utilization should be improved for $16 \%$. Similarly efficiency of other processes should be improved according values in Table 7.

\subsection{Output Increasing}

Turnover is very important indicator for distribution channel operating. Turnover can be expresses in different units: monetary units, pallets, inventory turnover, etc. Turnover increasing depends of many factors and can be improved synchronized action of all subsystems. Lower turnover is often the result of poor organization of the system and the inability to realize the delivery. In the observed example turnover number of deliveries should be increased of $19 \%$, packaging units for $34 \%$ and transported pallets for $16 \%$.

\section{Conclusions}

In this paper new methodological approach for measuring and improving efficiency is proposed. The approach is tested on the numerical example. The results of the proposed model can serve as guidance and provide a framework for making decisions 
about logistics processes and activities in product distribution. The efficiency in distribution channels can be improved applying certain corrective actions: improving information system, failure decreasing, increasing resource utilization and output increasing. For each corrective action detailed instructions are given.

There are different factors (for example: technology, product, the volume of business, the environment, etc.) that affect efficiency of logistics processes in distribution logistics. According results proposed approach can be used for efficiency improvement in different distribution channels and logistics systems. In the future research it is necessary to investigate the possibilities of measuring and improving efficiency of activities in observed processes and definition of indicators with special emphasis on quality and logistics failure indicators. It is also important to identify and statistically confirms the importance of factors that affect efficiency.

\section{Acknowledgements}

This paper was supported by the Ministry of Education, Science and Technological Development of the Republic of Serbia, through the project TR 36006.

\section{References}

Adler, N.; Golany, B. 2001. Evaluation of deregulated airline networks using data envelopment analysis combined with principal component analysis with an application to Western Europe, European Journal of Operational Research, 132(2): 260-273.

Adler, N.; Golany, B. 2002. Including principal component weights to improve discrimination in data envelopment analysis, Journal of Operations Research Society of Japan, 53(9): 985-991.
Andrejić, M. 2015. Models for measuring and improving efficiency of logistics processes in product distribution, PhD thesis, University of Belgrade, Faculty of Transport and Traffic Engineering, Serbia.

Andrejić, M.; Kilibarda, M.; Popović, V. 2015. Logistics failures in distribution process. In Proceedings of the 2 nd International Logistics conference, 247-253.

Andrejić, M.; Kilibarda, M. 2015. Distribution channels selection using PCA-DEA approach, International Journal for Traffic and Transport Engineering, 5(1): 74-81.

Chakraborty, P.S.; Majumder, G.; Sarkar, B. 2011. Performance measurement of distribution centre combining data envelopment analysis and analytic hierarchy process, Advances in Production Engineering \& Management, 6(2): 117-128.

Charnes, A.; Cooper, W.W.; Rhodes, E. 1978. Measuring efficiency of decision making units, Europen Journal of Operations Research, 2(6): 429-444.

Fawcett, S.E.; Cooper, M.B. 1998. Logistics performance measurement and customer success, Industrial Marketing Management, 27(4): 341-357.

Frazelle, E. 2002. Supply Chain Strategy: the logistics and supply chain management, McGraw-Hill, New York.

Hackman, S.; Frazelle, E.; Griffin, P.; Griffin, S.; Vlasta, D. 2001. Benchmarking Warehousing and Distribution Operations: An Input-Output Approach, Journal of Productivity Analysis, 16(1): 79-100.

Hamdan, A.; Rogers, K.J. 2008. Evaluating the efficiency of 3PL logistics operations, International Journal Production Economics, 113(1): 235-244.

Higginson, J.K.; Bookbinder, J.H. 2005. Distribution Centres in Supply Chain Operations Chapter in Langevin, A., and Riopel, D., Logistics Systems: Design and Optimization, 67-91, Kluwer. 
Hervani, A.A.; Helms, M.M.; Sarkis, J. 2005. Performance measurement for green supply chain management, Benchmarking: An International Journal, 12(4): 330-353.

Kalenoja, H.; Kallionpää, E.; Jarkko Rantala, J. 2011. Indicators of energy efficiency of supply chains, International Journal of Logistics: Research and Applications, 14(2): 77-95.

Kotzab, H.; Bjerre, M. 2005. Retailing in a SCMperspective. In Kotzab, H. (Ed.), Retailing the the contect of IT and distribution, Copenhagen: Copenhagen Business School Press.

Neely, A.; Gregory, M.; Platts, K. 1995. Performance measurement system design: A literature review and research agenda, International Journal of Operations and Production Management, 15(4): 80-116.
Ross, A.; Droge, C. 2002. An integrated benchmarking approach to distribution center performance using DEA modeling, Journal of Operations Management, 20(1): 19-32.

Rushton, A.; Croucher, P.; Baker, P. 2006. The handbook of logistics and distribution management, 3rd edition, Kogan page, London and Philadelphia.

Sarkis, J.; Talluri, S. 2004. Ecoefficiency measurement using data envelopment analysis: research and practitioner issues, Journal of Environmental Assessment Policy and Management, 6(1): 91-123.

Zhu, J. 2008. Quantitative Models for Performance Evaluation and Benchmarking Data Envelopment Analysis with Spreadsheets, Second Edition, Springer. 